\title{
Continuous lactation in dairy cows: effects on feed intake, milk production, and mammary nutrient extraction*
}

\author{
T.G. Madsen ${ }^{1}$, J.B. Andersen ${ }^{2}$, K.L. Ingvartsen ${ }^{2}$ and M.O. Nielsen ${ }^{1,3}$ \\ ${ }^{1}$ Department of Animal and Veterinary Basic Sciences, \\ The Royal Veterinary and Agricultural University \\ Groennegaardsvej 7, DK-1870 Frederiksberg C, Denmark \\ ${ }^{2}$ Department of Animal Health and Animal Welfare, Danish Institute of Agricultural Sciences, \\ Research Centre Foulum \\ P.O. Box 50, DK-8830 Tjele
}

\begin{abstract}
The effect of the pre-partum dry period was investigated in two groups of cows, either dried-off 7 weeks pre-partum or milked continuously into the next lactation, omitting the dry period. Continuous lactation decreased milk yield in the following lactation by appr. $24 \%$. This was associated with a lower mammary capacity for nutrient uptake and extraction. Continuously milked cows were less metabolically stressed in the periparturient period, probably due to lower milk production. This partly explains the observed elevated milk protein content in these cows. The magnitude of change considered, local regulatory mechanisms must have been affected as well.
\end{abstract}

KEY WORDS: periparturient period, glucose, acetate, ß-hydroxy-butyrate, NEFA

\section{INTRODUCTION}

Several experimental studies in dairy cows (peak milk yields $<40 \mathrm{~kg} /$ day) have demonstrated that omission of the dry period in dairy cows reduces milk yield in the following lactation by 20-40\% (see e.g., Swanson, 1965; Remond et al., 1997). Recently it was, however, reported that milk production in bST (bovine somatotropin) treated high yielding cows was not affected by omission of the dry period (Annen et al., 2003).

\footnotetext{
* Supported by the Danish Agricultural and Veterinary Research Council and Danish Cattle

${ }^{3}$ Corresponding author: e-mail: mon@kvl.dk
} 
Some of the most important hormones controlling mammary redevelopment in late pegnancy are ST and IGF-1 (Accorsi et al., 2002). It is therefore tempting to hypothesise that selection for high milk production, which is also associated with selection for high levels of ST, has resulted in cows less sensitive towards elimination of the dry period. We aimed to study if omission of the dry period in non-bST treated and relatively high yielding dairy cows: 1. is possible without major negative impact on subsequent milk production, 2. will result in a metabolically less stressful transition to the new lactation, and 3. change mammary nutrient affinity.

\section{MATERIAL AND METHODS}

All surgical and animal experimental procedures were conducted under protocols approved by the Danish authorities. In total 28 Danish Holstein cows with a production level of appr. $9000 \mathrm{~kg}$ ECM/cow annually were used. Eight weeks pre-partum cows were allocated to one of two groups. One group (14 cows) was dried off 7 weeks before expected parturition, and the other group (14 cows) was milked continuously into the next lactation. Cows were fed the same total mixed diet (7.18 MJ net energy/kg DM). It was fed restrictedly to cows in the dry group during the first 4 weeks of the dry period, otherwise ad libitum.

Blood samples from jugular and epicastric subcutaneous abdominal veins (milk veins) were taken simultaneously one week post-partum at 7.00, 10.00, 13.00 and $16.00 \mathrm{~h}$.

Milk composition was determined by near-infrared spectroscopy. Plasma glucose, acetate, $\beta$-hydroxybutyrate (BHB) and non-esterified fatty acids (NEFA) were determined by commercially available spectrophotometric kits.

Mammary extraction rates of metabolites were estimated as jugular-milk vein concentration difference (JM) as a percentage of jugular concentration (JV).

Temporal differences and treatment effects were estimated using the restricted maximum likelihood method in the mixed model procedure in SAS (SAS Institute Inc., Cary, NC 27513-2414, USA). All results are expressed as least squares means (LS-means) with standard error of mean (SEM).

\section{RESULTS}

\section{The following early lactation}

Pre-partum treatment did not affect the average feed intake the first 7 weeks post-partum, whereas milk yield was approximately $24 \%$ lower in this period in the continuously milked cows, as shown in Table 1.

The protein content in milk was significantly increased in the continuously lactating cows, whereas milk fat content was unaffected by treatment. 
Table 1. Mean values for milk yield and composition the first 7 weeks post-partum in dairy cows with or without a dry period pre-partum

\begin{tabular}{|c|c|c|c|c|}
\hline \multirow{2}{*}{$\begin{array}{c}\text { LS-means } \\
\text { SEM }^{2}\end{array}$} & \multicolumn{2}{|c|}{ Treatment } & \multirow{2}{*}{ SED $^{1}$} & \multirow{2}{*}{ P-value } \\
\hline & dry period & no dry period & & \\
\hline Feed intake, $\mathrm{kg} / \mathrm{d}$ & $22.7(0.8)$ & $21.5(0.7)$ & 1.1 & 0.26 \\
\hline Milk yield, $\mathrm{kg} / \mathrm{d}$ & $41.8(1.5)$ & $31.8(1.4)$ & 1.9 & $<0.01$ \\
\hline Protein, $\mathrm{g} / \mathrm{kg}$ & $32.5(0.5)$ & $36.2(0.5)$ & 0.06 & $<0.01$ \\
\hline Fat, $\mathrm{g} / \mathrm{kg}$ & $42.8(1.3)$ & $42.4(1.2)$ & 0.16 & 0.95 \\
\hline
\end{tabular}

${ }^{1}$ standard error of difference; ${ }^{2}$ standard error of means

In week one post-partum JV plasma glucose concentrations were lowest in the cows with a normal dry period pre-partum, and plasma BHB and NEFA tended to be higher, whereas acetate was unaffected by pre-partum treatment, as shown in Table 2.

Despite the differences in systemic glucose concentrations, glucose JM did not differ between treatment groups. Therefore mammary extraction rates were higher in the pre-partum dried-off cows for glucose. For acetate and BHB JM was found to be higher in the dried-off cows, however, because of elevated jugular levels of BHB, mammary extraction rate was only increased for acetate. The increase in NEFA jugular level resulted in a positive JM and thereby higher mammary extraction rate compared to the continuously milked cows.

Table 2. Jugular vein plasma concentration (JV) and mammary extraction rates (E) for glucose, acetate, $\beta$-hydroxybutyrate (BHB) and non-esterified fatty acids (NEFA) one week post-partum in dairy cows managed with or without a dry period pre-partum

\begin{tabular}{|c|c|c|c|c|c|}
\hline \multirow{2}{*}{\multicolumn{2}{|c|}{$\begin{array}{c}\text { LS-means } \\
\text { SEM }^{2}\end{array}$}} & \multicolumn{2}{|c|}{ Treatment } & \multirow{2}{*}{$\mathrm{SED}^{1}$} & \multirow{2}{*}{ P-value } \\
\hline & & dry period & no dry period & & \\
\hline \multirow[t]{2}{*}{ Glucose } & $\mathrm{JV}, \mathrm{mM}$ & $3.08(0.11)$ & $3.70(0.10)$ & 0.15 & $<0.01$ \\
\hline & E, \% & $24.3(1.3)$ & $20.4(1.2)$ & 1.8 & 0.04 \\
\hline \multirow[t]{2}{*}{ Acetate } & $\mathrm{JV}, \mathrm{mM}$ & $0.85(0.06)$ & $0.74(0.06)$ & 0.08 & 0.29 \\
\hline & $\mathrm{E}, \%$ & $47.9(2.3)$ & $38.2(2.1)$ & 3.1 & $<0.01$ \\
\hline \multirow[t]{2}{*}{ BHB } & $\mathrm{JV}, \mathrm{mM}$ & $2.20(0.23)$ & $1.61(0.21)$ & 0.31 & 0.07 \\
\hline & E, $\%$ & $19.9(3.1)$ & $24.4(2.8)$ & 4.2 & 0.29 \\
\hline \multirow[t]{2}{*}{ NEFA } & $\mathrm{JV}, \mu \mathrm{M}$ & $521(71)$ & $334(62)$ & 94 & 0.06 \\
\hline & E, $\%$ & $23.4(7.2)$ & $-1.2(6.5)$ & 9.7 & 0.02 \\
\hline
\end{tabular}

${ }^{1}$ standard error of difference; ${ }^{2}$ standard error of means

\section{DISCUSSION}

Our results support data from previous studies with less productive cows that omission of the dry period has a substantial negative effect on milk production in the following lactation (Remond et al., 1992). In non-bST treated cows, the dry period pre-partum is therefore essential to ensure that the dairy cow exploits her production potential in the following lactation. 
The current European Union milk pricing system encourages milk with high protein content. Milk protein content is difficult to manipulate compared to fat content. It is therefore of considerable interest to elucidate the mechanisms underlying the substantial increases (appr. $0.4 \%$-units) in protein content in milk from continuously lactating cows.

Despite differences in milk production, feed intakes were similar in the two groups of cows. The continuously milked cows were therefore less metabolically challenged by onset of the new lactation, which was also reflected in the profiles of metabolites in plasma.

In pre-partum dried-off compared to continuously milked cows, mammary extraction rates and JM were higher for glucose, acetate, NEFA and BHB (except for extraction rate). Based on the metabolite profiles in plasma we would however have expected lower JM and unaltered extraction rates for glucose and unaltered $\mathrm{JM}$ and extraction rates for acetate. JM is normally closely linked to systemic plasma concentrations for acetate, BHB and NEFA and to a minor extent this is also true for glucose. Our findings therefore suggest that continuation of milk synthesis interferes with mechanisms responsible for full restoration of mammary secretory cell activity prior to parturition.

\section{CONCLUSIONS}

In non-bST treated dairy cows, the pre-partum dry period was essential to restore full mammary secretory activity in the following lactation. This includes restoration of mammary capacity for nutrient uptake and extraction.

Continuous lactation decreased the metabolic stress associated with initiation of new lactation. However, this could primarily be due to a lower mammary nutrient pull, as feed intake capacity was not improved.

Improved energy status in early lactation partly explains the higher protein content in milk in continuously lactating cows. The magnitude of change considered, local regulatory mechanisms must surely have been affected as well.

\section{REFERENCES}

Accorsi P.A., Pacioni B., Pezzi C., Forni M., Flint D.J., Seren E., 2002. Role of prolactin, growth hormone and lisulin-like growth factor 1 in mammary gland involution in the dairy cow. J. Dairy Sci. 85, 507-513

Annen E.L., McGuire M.A., Vicini J.L., Collier R.J., 2003. Effect of POSILAC (bST) and dry period management strategy on milk yield. J. Dairy Sci. 86, Suppl., 154

Remond B., Ollier A., Miranda G., 1992. Milking of cows in late pregnancy: milk production during this period and during the succeeding lactation. J. Dairy Res. 59, 233-241

Remond B., Kerouanton J., Brocard V., 1997. The effect of reducing or omitting the dry period on the performance of dairy cows. Prod. Anim. 10, 301-315

Swanson E.W., 1965. Comparing continuous milking with sixty day dry periods in successive lactations. J. Dairy Sci. 48, 1205-1209 